\title{
A Comparative Nitrogen Balance and Productivity Analysis of Legume and Non-legume Supported Cropping Systems: The Potential Role of Biological Nitrogen Fixation
}

OPEN ACCESS

Edited by:

Patrick Brown

University of California, Davis, USA

Reviewed by:

Heiner Goldbach,

University of Bonn, Germany

Sat Darshan Singh Khalsa,

University of California, Davis, USA

*Correspondence:

Pietro P. M. lannetta

pete.iannetta@hutton.ac.uk

Specialty section:

This article was submitted to

Plant Nutrition

a section of the journal

Frontiers in Plant Science

Received: 03 August 2016

Accepted: 28 October 2016

Published: 21 November 2016

Citation:

lannetta PPM, Young M, Bachinger J, Bergkvist G, Doltra J,

Lopez-Bellido RJ, Monti M, Pappa VA, Reckling M, Topp CFE, Walker RL, Rees RM, Watson CA, James EK, Squire GR and Begg GS (2016) A Comparative Nitrogen Balance and

Productivity Analysis of Legume and Non-legume Supported Cropping Systems: The Potential Role of Biological Nitrogen Fixation.

Front. Plant Sci. 7:1700

doi: 10.3389/fpls.2016.01700
Pietro P. M. lannetta ${ }^{1 *}$, Mark Young ${ }^{1}$, Johann Bachinger ${ }^{2}$, Göran Bergkvist ${ }^{3}$, Jordi Doltra ${ }^{4,5}$, Rafael J. Lopez-Bellido ${ }^{6}$, Michele Monti ${ }^{7}$, Valentini A. Pappa ${ }^{8,9}$, Moritz Reckling ${ }^{2,3}$, Cairistiona F. E. Topp ${ }^{8}$, Robin L. Walker ${ }^{8}$, Robert M. Rees ${ }^{8}$, Christine A. Watson ${ }^{3,8}$, Euan K. James ${ }^{1}$, Geoffrey R. Squire ${ }^{1}$ and Graham S. Begg ${ }^{1}$

${ }^{1}$ Ecological Sciences, James Hutton Institute, Dundee, UK, ${ }^{2}$ Leibniz-Centre for Agricultural Landscape Research, Institute of Land Use Systems, Müncheberg, Germany, ${ }^{3}$ Department of Crop Production Ecology, Swedish University of Agricultural Sciences, Uppsala, Sweden, ${ }^{4}$ Department of Agroecology and Environment, Aarhus University, Tjele, Denmark, ${ }^{5}$ Cantabrian Agricultural Research and Training Centre, Government of Cantabria, Muriedas, Spain, ${ }^{6}$ Eco-efficient Cropping Systems, University of Cordoba, Cordoba, Spain, ${ }^{7}$ Department of Agriculture, Mediterranea University of reggio Calabria, Reggio Calabria, Italy, ${ }^{8}$ Research Division, Scotland's Rural College, Edinburgh, UK, ${ }^{9}$ Department of Crop Science, Agricultural University of Athens, Athens, Greece

The potential of biological nitrogen fixation (BNF) to provide sufficient $\mathrm{N}$ for production has encouraged re-appraisal of cropping systems that deploy legumes. It has been argued that legume-derived $\mathrm{N}$ can maintain productivity as an alternative to the application of mineral fertilizer, although few studies have systematically evaluated the effect of optimizing the balance between legumes and non $\mathrm{N}$-fixing crops to optimize production. In addition, the shortage, or even absence in some regions, of measurements of BNF in crops and forages severely limits the ability to design and evaluate new legume-based agroecosystems. To provide an indication of the magnitude of BNF in European agriculture, a soil-surface $\mathrm{N}$-balance approach was applied to historical data from 8 experimental cropping systems that compared legume and non-legume crop types (e.g., grains, forages and intercrops) across pedoclimatic regions of Europe. Mean BNF for different legume types ranged from 32 to $115 \mathrm{~kg} \mathrm{ha}^{-1}$ annually. Output in terms of total biomass (grain, forage, etc.) was 30\% greater in non-legumes, which used $\mathrm{N}$ to produce dry matter more efficiently than legumes, whereas output of $\mathrm{N}$ was greater from legumes. When examined over the crop sequence, the contribution of BNF to the $\mathrm{N}$-balance increased to reach a maximum when the legume fraction was around 0.5 (legume crops were present in half the years). BNF was lower when the legume fraction increased to 0.6-0.8, not because of any feature of the legume, but because the cropping systems in this range were dominated by mixtures of legume and non-legume forages to which inorganic $\mathrm{N}$ as fertilizer was normally applied. Forage (e.g., grass and clover), as opposed to grain crops in this range maintained high outputs of biomass and $\mathrm{N}$. In conclusion, BNF through grain and forage legumes has the potential to generate major benefit in terms of reducing or dispensing with the need for mineral $\mathrm{N}$ without loss of total output.

Keywords: legumes, biological nitrogen fixation, crop rotation, nitrogen balance, productivity 


\section{INTRODUCTION}

Many legumes (plants of the family Fabaceae) form a symbiotic association with types of bacteria that are collectively termed "rhizobia" (Sprent and Sprent, 1990). The rhizobia fix inert atmospheric nitrogen $(\mathrm{N})$ into biologically useful forms within legume root nodules in a process called "biological $\mathrm{N}$ fixation" (BNF; Sprent, 2009). This symbiotic association is the largest natural source of the $\mathrm{N}$ cycled to sustain natural systems (Vitousek et al., 2002). In addition, BNF by grain and forage legumes plays an important role enriching the pools of soil $\mathrm{N}$ for non-N-fixing crops grown after the legumes as part of a strategic cropping sequence or rotation (Bullock, 1992).

Since the discovery of the Haber-Bosch process and the production of anthropogenically produced inorganic $\mathrm{N}$ plant fertilizer (Erisman et al., 2008), the ecological and economic dependency of farmed systems on legumes has diminished greatly. For example, the area of European farmland cropped with legumes declined from 11.3 million ha in 1961, to about 3.4 million ha in 2005 (Rochon et al., 2004). This reflects the general preference of farmers for inorganic $\mathrm{N}$-fertilizer which enables the cultivation of non-legume crops commanding higher values in the marketplace and hence greater profit.

Despite the reduction in legume cropping, Europe still relies heavily on legumes for animal feed in the form of imports, especially of soybean (Glycine max L. Merr.). European agriculture consumes $25 \%$ of the world soybean crop, mainly to sustain livestock production (Steinfeld et al., 2006; UNEP and WHRC, 2007). This trade in soybean encourages tropical deforestation (Simon and Garagorry, 2005; Nepstad et al., 2006). Moreover, the inefficient use of $\mathrm{N}$ causes eutrophication and acidification of water, and is responsible for most of the greenhouse gas emissions from farming (Houghton, 1996; Vitousek et al., 1997; EEA, 2007; Sutton et al., 2011).

These environmental concerns, in conjunction with political pressures and market forces that include fuel- and foodinsecurity, has made the "sustainable intensification" of cropping systems a main aim of government policy makers (Foresight, 2011). Embodied within this aim is a reappraisal of legumesupported cropping systems, particularly to exploit BNF (Drinkwater et al., 1998), with the aim to mitigate the inefficient use of $\mathrm{N}$ and energy in current cropping systems (Hansen, 2000; Hanson et al., 2007). Increasing the proportion of legume crops in a rotation will reduce the use of inorganic fertilizer, increase the proportion of renewable resources of $\mathrm{N}$ in global nutrient cycles (Foley et al., 2011; Seufert et al., 2012) and may also decrease the quantity of reactive $\mathrm{N}$ lost from the ecosystem.

The impact of the rapid disappearance of legumes from European agriculture remains poorly understood. Agronomic experiments using legumes have neither been coordinated across climatic regions nor analyzed in a consistent manner to quantify the main flows of $\mathrm{N}$ in and out of crops and forages. Moreover, in some comparisons, e.g., of organic systems that include legumes against conventional systems that typically do not contain legumes, the productivity of the systems with legumes is generally lower (Seufert et al., 2012). Therefore, there are questions about the ability of legume-based systems to produce output of biomass and $\mathrm{N}$ at rates comparable to those of non-legume systems. Accordingly the promotion of legumes in high intensity cropping systems has been difficult to justify. To address this, a comparative "soil-surface N-balance" analysis (Parris, 1998; OECD, 2001), was carried out using data from legume and non-legume supported crop systems at experimental sites that spanned a wide range of cropping systems and pedoclimatic regions across Europe. "Legume inclusion" was defined as the presence of a legume when considering a single croppingyear or the proportion of such years when considering crop sequences, termed "legume fraction." This approach facilitated a comparative analysis of low-input legume based approaches and conventional approaches. The main questions that are addressed for both single crops and cropping sequences were the degree to which BNF by legumes compensates for the application of mineral $\mathrm{N}$, whether or not legume based rotations contribute to lower surpluses of $\mathrm{N}$, and whether primary production and output as biomass and $\mathrm{N}$ are reduced by the inclusion of legumes.

\section{MATERIALS AND METHODS}

\section{Data Sources}

Eight case studies of legume based cropping systems originally undertaken as independent trials by the authors were selected. These varied substantially in terms of region, farm system, and experimental design (Table 1). The studies included simple designs of short duration (3 years) to test the benefit of legumes on the yields of following crops, to long-term experiments that monitored the performance of complex legume-based rotations. The systems included arable only, pasture only (grazed, silaged), and mixed systems producing a wide range of legume and non-legume grain, silage and forage products. A number of cropping practices were also included in the systems, namely monocultures, mixtures, intercrops, undersown crops, catch crops and green manures. Together, the eight studies included 29 different main-crops, 59 different maincrop/sub-crop combinations (a sub-crop being defined as an undersown crop or one of the components of an intercrop) and 25 different crop sequences (Table 1).

\section{N Balance Calculations}

A soil-surface $\mathrm{N}$-balance analysis was performed in which $\mathrm{N}$ inputs and outputs were measured or estimated to allow calculation of $\mathrm{N}$ surplus ( $\mathrm{N}$ input $-\mathrm{N}$ output) and $\mathrm{N}$ use efficiency (NUE, N output / $\mathrm{N}$ input; OECD, 2001, 2008) for each crop combination for each year of a crop sequencedefined here as a "crop-year." The input and output data were measured or estimated at the scale of the experimental plot, independently for each plot replicate (where these were present). An $\mathrm{N}$ balance for the crop sequence was calculated for each experimental plot by summing the annual balances across the sequence. This sum was then divided by the length in years of the crop-sequence to produce an annual average crop sequence $\mathrm{N}$ balance, thereby accounting for the variation in the duration of the crop sequences. 


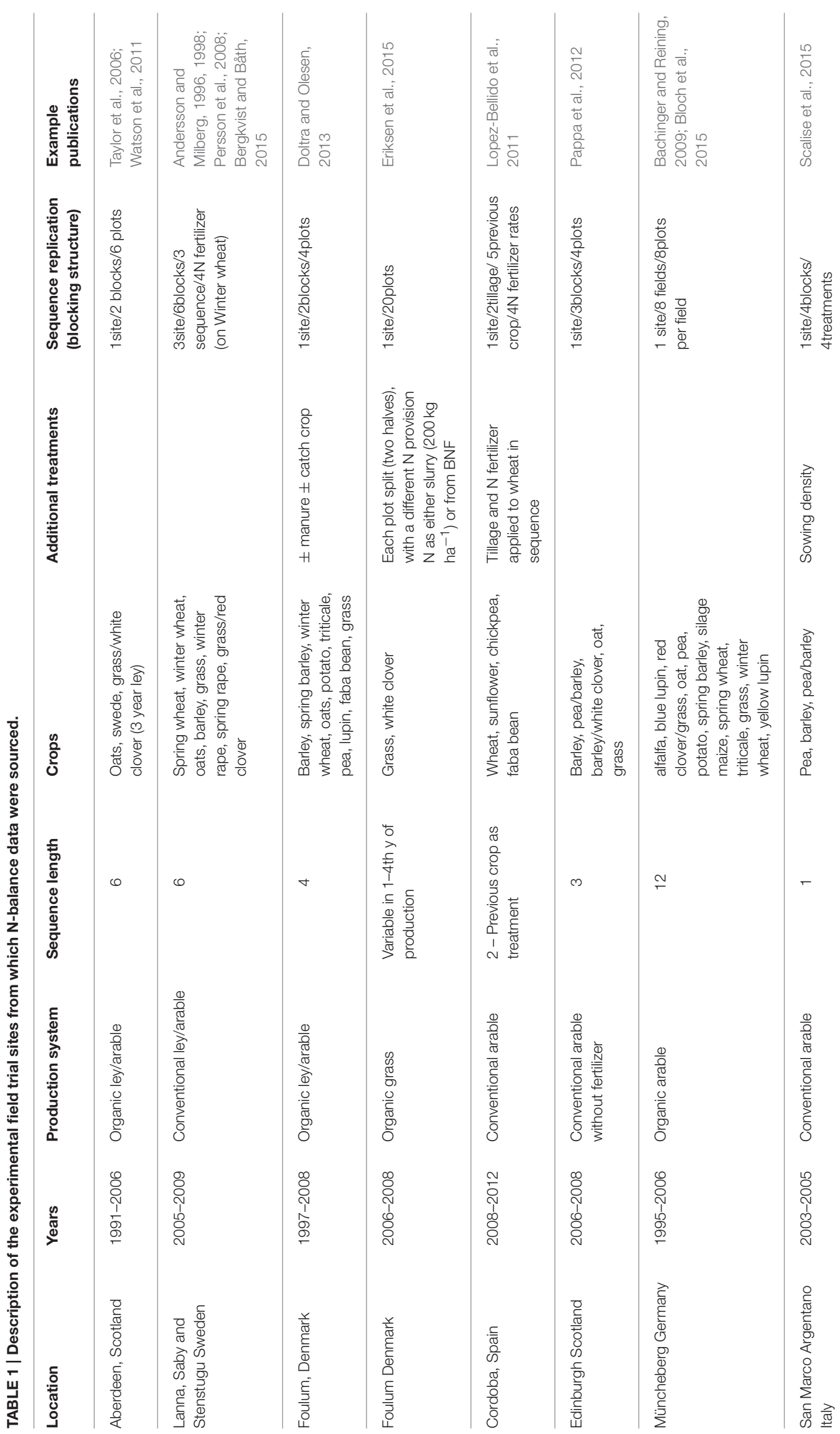




\section{N Inputs}

\section{$N$ Application as inorganic or organic fertilizer}

All experiments reported the application rates for inorganic $\mathrm{N}$ $\left(\mathrm{kg} \mathrm{N} \mathrm{ha}^{-1}\right)$. Organic manure was added to a number of plots and in various forms: solid or slurry, cattle, pig or poultry. The manure application rate $\left(\mathrm{kg} \mathrm{ha}^{-1}\right)$ was corrected for dry weight where necessary and multiplied by the total $\mathrm{N}$ concentration of the manure to give the $N$-in $\left(\mathrm{kg} \mathrm{N} \mathrm{ha}^{-1}\right)$. Where manure $\mathrm{N}$ concentration was not measured, generic values were taken from the UK Department for Environment, Food and Rural Affairs (DEFRA) Fertilizer Manual RB209 (DEFRA, 2010).

\section{Seed $N$}

The $\mathrm{N}$ derived from sown seed was estimated by multiplying sowing rates $\left(\mathrm{kg} \mathrm{ha}^{-1}\right)$ with seed $\mathrm{N}$ content $\left(\mathrm{kg} \mathrm{N} \mathrm{kg}^{-1}\right)$ either reported by the studies or obtained from the literature. When sowing rates were reported as the number of seeds $\left(\mathrm{m}^{-2}\right)$, values were converted to $\mathrm{kg} \mathrm{ha}^{-1}$ on the basis of thousand seed weight values obtained from the literature.

\section{Biological Nitrogen Fixation (BNF)}

The method of Korsaeth and Eltun (2000) allowed BNF to be estimated in the absence of direct measurement using factors and relations obtained from the literature (Equation 1). This approach was considered sufficiently general that it could be applied to the full range of cropping systems and legume types for the available data.

Adapting this method to the calculation of annual BNF, the $\mathrm{N}$ fixed $\left(N_{f i x}\right)$ by each of the $i$ legumes present within a stand over each of the $j$ harvests, which in the case of silage might include several cuts in 1 year is:

$$
N_{f i x}=\sum_{i} \sum_{j} L_{i j} N_{l e g i j} F_{j} R_{j}
$$

where $L$ is the above-ground biomass of the harvested legumes $\left(\mathrm{kg} \mathrm{ha}^{-1}\right), N_{\text {leg }}$ is an assumed fraction for crop $\mathrm{N}$ composition, $F$ is proportion of legume $\mathrm{N}$ derived from air by BNF, and $R$ is the ratio of shoot to total plant biomass for each legume. In addition, $F$ is assumed to be sensitive to the amount of inorganic $\mathrm{N}$ in the soil. The proportion of $\mathrm{N}$ present within a plant derived from $\mathrm{BNF}$ is greatest in the absence of any inorganic $\mathrm{N}$ and declines in a linear way with the increasing application of inorganic $\mathrm{N}$, i.e.,

$$
F_{j}=F_{\text {max }}-a_{j} N_{\text {inorganic }}
$$

Here it is assumed that inorganic $\mathrm{N}\left(\mathrm{kg} \mathrm{N} \mathrm{ha}^{-1}\right)$ can be derived from chemical fertilizer and the inorganic component in organic fertilizers.

\section{Outputs}

Nitrogen output was estimated on the basis of the amount of $\mathrm{N}$ removed from the system in crop biomass and livestock. Losses of $\mathrm{N}$ to the atmosphere and through leaching were not available in all cases and hence were not accounted for.

\section{Harvest of crop}

Depending on the experimental treatment, harvested material was either removed from the plots or left to be incorporated at a later stage. In most cases, a separate biomass measurement was reported for each component of this output; otherwise, a total biomass and relative proportion of each component was reported from which output biomass was then calculated. The amount of $\mathrm{N}$ removed from the plot at harvest was calculated using the $\mathrm{N}$ fraction of each component. Where the $\mathrm{N}$ fraction was not measured directly, estimates were taken from the literature.

\section{Livestock}

Livestock were assumed to contribute to $\mathrm{N}$ losses by the consumption and assimilation of $\mathrm{N}$ through grazing and the subsequent removal of the animals from the plot or field. Where it took place, grazing was by sheep and was reported in terms of livestock unit grazing days (LUGD) from which $\mathrm{N}$ consumption was calculated as follows:

$$
N_{\text {consumption }}=L U G D \times W_{L U G D} \times C \times N_{\text {forage }}
$$

Here $L U G D$ is converted to a weight equivalent given a livestock unit weight $\left(W_{L U G D}\right)$ of $650 \mathrm{~kg}$ (c.f. DEFRA, 2011), and multiplied by a consumption rate $(C)$ in sheep of $3 \%$ body-mass per day and the fractional composition of $\mathrm{N}$ in the forage crops $\left(N_{\text {forage }}\right)$. To account for the return of $\mathrm{N}$ to the field through excretion, it was assumed that $10 \%$ of consumed $\mathrm{N}$ was assimilated and retained by the sheep (IPCC, 2006; Table 10.22).

\section{Productivity}

The biomass $\left(\mathrm{kg} \mathrm{ha}^{-1}\right)$ of crop output, including grain, straw and silage, was derived for each year of each crop sequence to provide a measure of productivity. Biomass output efficiency $(B O E)$ was calculated as the biomass of crop output achieved for each kilogram of $\mathrm{N}$ input.

\section{Data Analysis}

The influence of legume cropping on $\mathrm{N}$ balances was analyzed in terms of $\mathrm{N}$ input $(\mathrm{N}-\mathrm{in})$, the contributions to this from the application of fertilizer (N-fert) and from BNF $(\mathrm{N}-f i x), \mathrm{N}$ output (N-out), N surplus (N-surp), the difference between $\mathrm{N}$-in and N-out, and $\mathrm{N}$ use efficiency (NUE; N-out / N-in; OECD, 2008). The analysis also considered productivity in terms of the variables Biomass Output and Biomass Output Efficiency ( $B O$ and $B O E$, respectively). Together these are referred to as the "N balance variables." The analysis was conducted in 2 parts, the first addressing the annual $\mathrm{N}$ balance variables for crop-year and second the annual average crop-sequence $\mathrm{N}$ balances.

\section{Annual N Balance}

The frequency distributions of the $\mathrm{N}$ balance variables across datasets, plots and years were positively skewed and included a number of zero values (with the exception of N-surp). A log plus constant transformation of the $\mathrm{N}$ balance variables resulted in a bimodal distribution, indicating that the experimental plots 
could be considered as falling into two populations. Firstly, those for which $\mathrm{N}$-in or $\mathrm{N}$-out were zero or very small and secondly, those with a positive $\mathrm{N}$-in and N-out (Table 2). Thresholds to discriminate between these populations were selected by examination of their bimodal frequency distributions. Whether a plot received an input or produced an output (i.e., positive $\mathrm{N}$-in or $\mathrm{N}$-out) was largely determined by the chosen crop management practices e.g., whether a legume was included, fertilizer applied, or silage removed after cutting. Therefore, these categorical states do not lend themselves to being considered as random variables suitable for statistical analysis. However, the proportion of observations falling into these categorical states has been used to describe the crop management conditions under which the experiments were carried out.

Data from the low value populations as defined (see Table 2) were excluded from further analysis. The $\mathrm{N}$ balance variables, comprised of high value observations only, were then treated as continuous variables and analyzed using linear mixed-effects models, following a natural log + constant transformation, with the exception of N-surp which was not transformed. In modeling all $\mathrm{N}$ balance variables, site and plot variables were included as random terms to account for consistent differences between experiments and between the experimental plots within each experiment. The hypothesis that there was no difference in the $\mathrm{N}$ balance variables between legume and non-legume crops was tested by a likelihood ratio test of competing models. For this analysis, the large number of different combinations of legumes, non-legumes, grain crops and forages was condensed into five comparisons, each consisting of a legume and a non-legume: (1) grain legume (e.g., faba bean) vs. grain non-legume (e.g., maize); (2) legume and non-legume grain crops (e.g., pea and barley), referred to as "grain mix" vs. grain non-legume (e.g., maize); (3) legume and non-legume forage crops (e.g., grass and clover), referred to as "forage mix" vs. forage non-legume (e.g., grass); (4) grain legume and non-legume forage (e.g., faba bean and rye) vs. grain and forage non-legume (e.g., oat and rye); and, (5) grain and forage legume (e.g., barley and clover) vs. grain and forage non-legume (e.g., barley and grass). Where different types of crop or forage were indicated in the above list, they were both grown at some point during the same year; no distinction was made as to whether the crops were grown in sequence or as intercrops.

Where appropriate, data were back transformed following analysis and values reported in $\mathrm{kg} \mathrm{ha}^{-1}$ to facilitate comparison with other data sources.

\section{Crop Sequence N Balance}

To evaluate the role of legumes within a crop sequence, the yearly average of each $\mathrm{N}$ balance variable was calculated for each crop sequence of 4 or more years. In addition, the proportion of years in which a legume crop was grown was calculated, as was the proportion of grain, forage and grain/ forage combinations.

The relation between each crop sequence $\mathrm{N}$ balance variable and the proportion of legume cropping in a crop sequence was examined and the significance tested by fitting a generalized additive model (GAM) to the data assuming Gaussian errors and an identity link-function. Each $\mathrm{N}$ balance variable was modeled independently as a smooth function of the proportion of years of a crop sequence that included legumes. The significance of the smooth term was then tested using Analysis of Deviance to compare the model against a second model from which the smooth term was excluded.

\section{RESULTS}

\section{N Balance: Crops \\ Broad Comparison with and without Fertilizer}

The crop-types are first arranged into three broad groupings defined by whether they included legumes and/or received mineral fertilizer (Figures 1A-F). The "legume" group (left hand side of each figure), comprised legumes either alone or in combination with another crop, and with a few exceptions did not receive mineral fertilizer in the year in question. The "legume mix + fertilizer" group (center in each part of Figure 1) included mixtures of legumes and non-legumes, for example where the legume is undersown, and where the crop in that year received mineral fertilizer. The "non-legume" group comprised single and mixed crops such as cereal, potato and grass which generally received mineral fertilizer.

TABLE 2 | The number of experimental plots (crops $\mathbf{y}^{-1}$ ), for which $\mathbf{N}$ balance variables were either low or high for set "value ranges" (kg N ha $\left.{ }^{-1}\right)^{\star}$.

\begin{tabular}{|c|c|c|c|c|c|c|c|c|c|c|}
\hline \multirow[t]{2}{*}{ Value range ( $\mathrm{kg} \mathrm{N} \mathrm{ha}^{-1}$ ) } & \multicolumn{2}{|c|}{$\mathbf{N}$ fertilizer } & \multicolumn{2}{|c|}{$\mathbf{N}$ fixed } & \multicolumn{2}{|c|}{$\mathbf{N}$ input } & \multicolumn{2}{|c|}{$\mathbf{N}$ output ${ }^{*}, \dagger$} & \multicolumn{2}{|c|}{ Biomass output ${ }^{\star}$} \\
\hline & [0 and 2] & [30 and 345] & 0 & $\geq 1$ & [0 and 25.5] & $>25.5$ & 0 & $\geq 1$ & 0 & $\geq 1$ \\
\hline Grain legume & 99 & 0 & 1 & 98 & 1 & 98 & 0 & 99 & 0 & 99 \\
\hline Grain mix & 36 & 2 & 0 & 38 & 0 & 38 & 0 & 38 & 0 & 38 \\
\hline Grain non-legume & 393 & 730 & 1123 & 0 & 389 & 734 & 22 & 1097 & 22 & 1101 \\
\hline Forage mix & 352 & 180 & 141 & 376 & 138 & 379 & 83 & 434 & 184 & 348 \\
\hline Forage non-legume & 44 & 102 & 124 & 22 & 36 & 110 & 0 & 146 & 0 & 146 \\
\hline Grain legume + forage & 73 & 1 & 0 & 74 & 0 & 74 & 0 & 74 & 0 & 74 \\
\hline Grain + forage legume & 86 & 152 & 203 & 30 & 66 & 167 & 0 & 232 & 0 & 237 \\
\hline
\end{tabular}

The sum of the number of low and high experimental plots is not consistent across $N$ balance variables in some cases due to missing observations.

*Zero values reported for $N$ - and Biomass-output variables reflect the fact that there was no removal of crop material from the system.

${ }^{\dagger}$ Output $N$ values do not include $N$ losses due to leaching or denitrification, as stated in the Materials and Methods. 

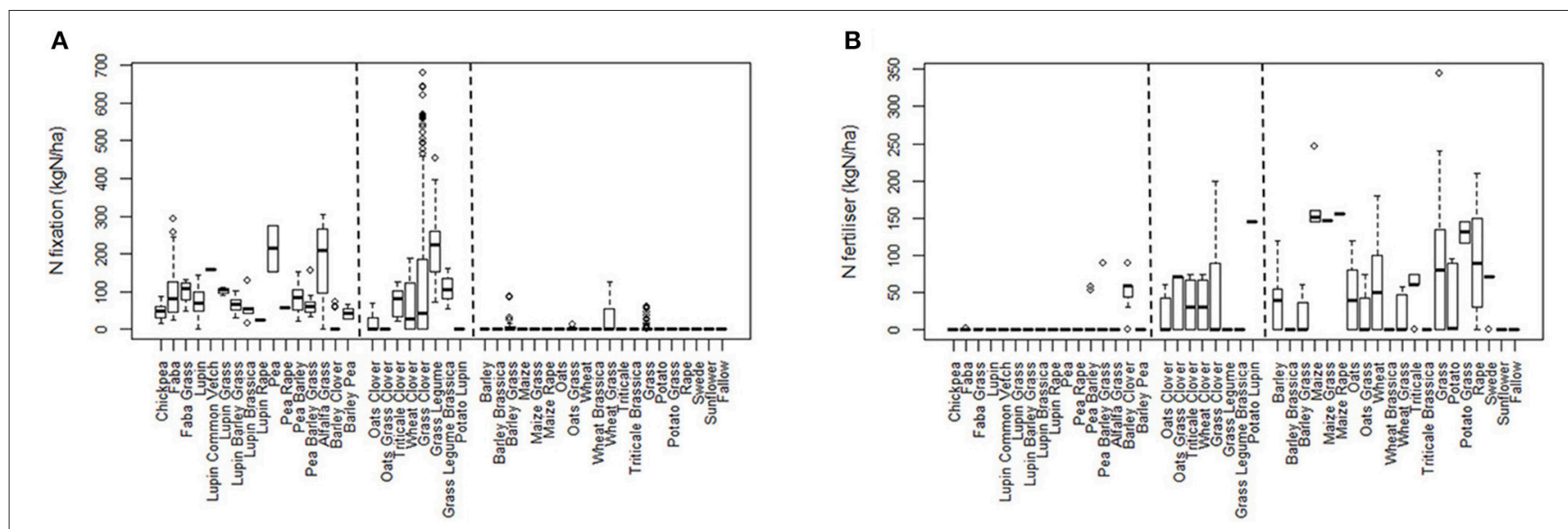

C

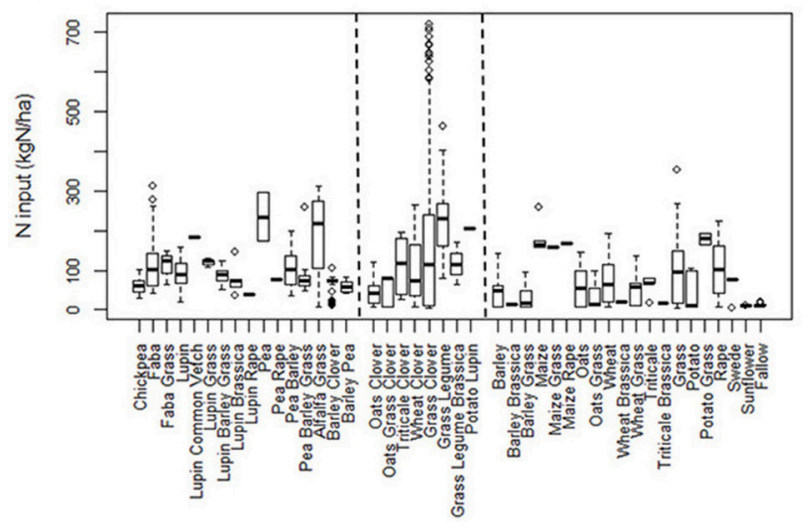

D
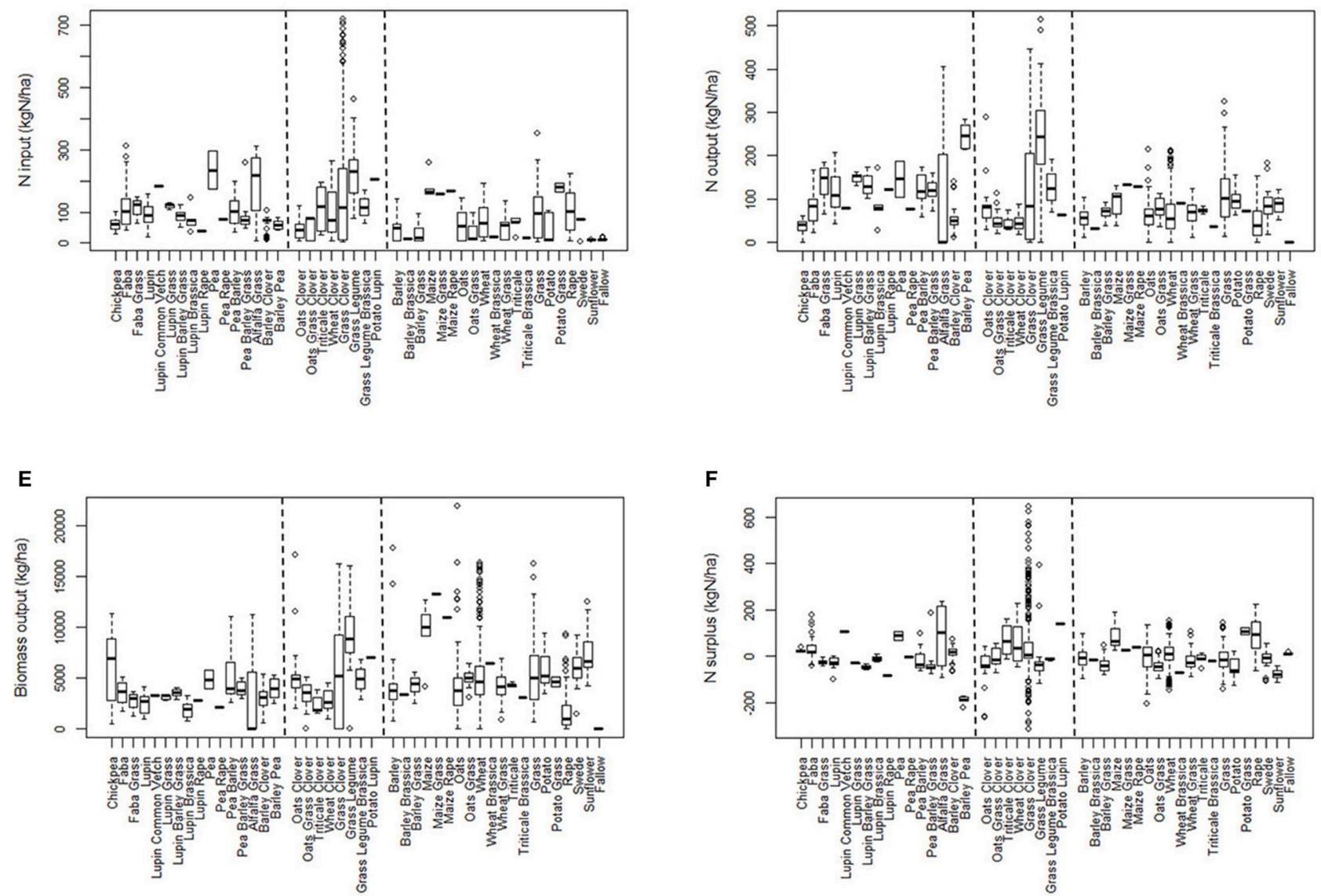

FIGURE 1 | Box and whisker plots showing the levels of: (A), N-fix; (B), N-fert; (C), N-in; (D), N-out; (E), N-surp (kg N ha ${ }^{-1}$ ); and, (F), Biomass output (kg ha ${ }^{-1}$ ) for all crop combinations. The first block of crops on the left side of the $\mathrm{x}$-axis consists of legumes that received no or very little fertilizer; the second block, legume and non-legume mixtures that generally received fertilizer; and the third block, non-legumes.

In interpreting these data, only $\mathrm{N}$-fert is based on measured inputs during the year, whereas the contribution from N-fix can only be accounted when biomass was removed from the field during the year in question. All the apparent BNF is accounted for in that 1 year if biomass had been accumulating for two or more years before its removal. This facet of the calculation is responsible for some of the very high values $\left(475-700 \mathrm{~kg} \mathrm{~N} \mathrm{ha}^{-1} \mathrm{y}^{-1}\right.$ ) of $\mathrm{N}$ input for grass-clover and grass-legume mixtures (Figure 1). 


\section{Specific Comparison of Different Crop-Types}

As defined in Materials and Methods, the data allowed specific comparisons between five types of crop and forage with and without a legume (Table 3 ). Biomass production averaged in these groupings ranged from 2.4 to $5.5 \mathrm{t} \mathrm{ha}^{-1}$ (back-transformed means). In all but one of the comparisons, the non-legume class produced significantly more biomass than the respective legume class. Only "forage non-legume" produced less than its comparator. Biomass across the five non-legume classes was on average 1.29-fold that of the legume (based on back-transformed values). In contrast, $\mathrm{N}$-out differed in the opposite direction to that of biomass itself, being greater in the legume than the nonlegume in four out of five comparisons (the exception being the grain + forage in mixed rotations; last 3 rows of Table 3 ). In terms of back-transformed means, the range of $\mathrm{N}$-out was 55 to $115 \mathrm{~kg} \mathrm{ha}^{-1}$. The greater $\mathrm{N}$ but smaller biomass values in the legume component reflects the generally higher $\% \mathrm{~N}$ in legume tissue compared to non-legume tissue.

Whether or not the majority was provided by N-fert or N-fix, $\mathrm{N}$-in was greater in the legume class in all five comparisons. In the cases where N-fix was estimated in a non-legume crop, this was due to BNF by legumes that were neither sown nor intended to be in the plot (e.g., legume forages as volunteer weeds). $\mathrm{N}$-surp varied substantially within and between experiments and experimental plots (see standard errors in Table 3), and for the majority of crop types it cannot be established whether grain crops, legume or non-legume, consistently produce either a surplus or deficit of $\mathrm{N}$.

The two "efficiencies" $B O E$ and NUE, were generally consistent with what might be expected from the other N-balance variables. In all cases, the non-legume, with its generally higher biomass output and lower $\mathrm{N}-i n$, achieved higher NUE and BOE. However, the output of biomass and $\mathrm{N}$ by the legumes was achieved in the absence, or reduced application of, fertilizer and hence was highly efficient in terms of biomass per unit $\mathrm{N}$ applied as fertilizer.

Unlike grain legumes which were grown alone, forage legumes were only grown in combination with non-legumes, either grain or forage. The combination of both legume and non-legume species blurred the distinction between these crop types, such that substantial amounts of $\mathrm{N}$-fert were applied to legume-containing forages and also BNF was estimated as positive in non-legume crops due to "contamination" by legumes grown previously. Among the three forage comparisons (Table 3) the vegetative crops (third comparison) whether legume (e.g., clover and grass), or non-legume (e.g., grass), gave the highest $\mathrm{N}$-in, $\mathrm{N}$-out and biomass.

\section{N Balance: Crop Sequence}

The average annual rate of $N$-fix did not increase monotonically with the proportion of legume crops but peaked at an intermediate proportion of legume crops (Figure 2A). To test the significance of this pattern, a generalized additive model (GAM) was fitted to the data in which average BNF was modeled as a smooth function of the proportion of years of a crop sequence that included legumes, excluding the $100 \%$ legume sequences.
The smooth term was significant $\left[\mathrm{F}_{(4.28,290)}=38.7, P<0.001\right]$ indicating a peak in BNF of 50-100 kg ha-1 (Figure 2A).

Though the variation in the average rate of $\mathrm{N}$ application between crop sequences was, to a large extent, independent of legume cropping, there was a significant reduction in $\mathrm{N}$-fert at approximately $50 \%$ legume fraction $\left[\mathrm{F}_{(2.66,291}=8.83, P<0.001\right.$; Figure 2B]. The trade-off between $N$-fert and $N$-fix, the two major sources of $\mathrm{N}$, acts to minimize the sensitivity of total $\mathrm{N}$-in to the extent of legume cropping (Figure 2C), although $N$-in was slightly elevated at intermediate levels of legume use $\left[\mathrm{F}_{(0.92,293)}=\right.$ $10.30, P=0.002$ ]. The trend in $\mathrm{N}$ output (Figure 2D) is similar to that of $N$-fix and $N$-in including a peak at intermediate levels of legume cropping $\left[\mathrm{F}_{(1.99,292)}=29.11, P<0.001\right]$.

The trade-off between $N$-fix and $N$-fert is, in part, to be expected as a consequence of the negative relationship between $\mathrm{N}$ application and BNF assumed in the calculation of $N$ fix (Equation 2). However, the increase in legume fraction is also associated with a shift in cropping system. For example, many sequences with a legume fraction above 0.6 were of a similar mixed cropping system dominated by a grazed grassclover ley. This is a largely vegetative combination, producing higher biomass and $\mathrm{N}$ output than other crops, but habitually given $\mathrm{N}$ fertilizer even though legumes were present in most years. The various compensations between $N$-fix and $N$-fert resulted in a broadly similar biomass output over a wide range of legume fractions (Figure 3), from around 25\% legume inclusion.

\section{DISCUSSION}

\section{Comparative Performance of Legume and Non-legume Crops}

The main questions to be answered by this analysis are whether BNF by legumes compensates for reduced input of mineral fertilizer and whether having a legume in a crop sequence reduces overall productivity. When analyzed by crop-year, the two measured variables, biomass and $\mathrm{N}$ fertilizer, were not tightly coupled i.e., large quantities of biomass were produced in the absence of fertilizer. Legumes had compensated by providing the $\mathrm{N}$ requirements in treatments that received no or reduced fertilizer. In all five assessments by crop-type (Table 3), the legume generated a higher $\mathrm{N}$-in through a combination of measured $N$-fert and estimated $N$-fix, than the non-legume comparator.

The observation that a mixture of legumes and non-legumes increases productivity is consistent with the observations of a large European study that analyzed the productivity of grass swards with differing proportions of clover (Suter et al., 2015). They suggested that competition for $\mathrm{N}, \mathrm{N}$ transfer, and niche complementarity could explain the synergies associated with such mixtures. In our study the effects of the legumes on productivity (here measured as output) was more complex and depended on how productivity was defined. Non-legumes, such as maize and grass, produced about 1.3-fold the biomass of legumes but about 0.75 -fold the $\mathrm{N}$ in the output, consistent with the generally higher $\% \mathrm{~N}$ of legumes. This general conclusion 


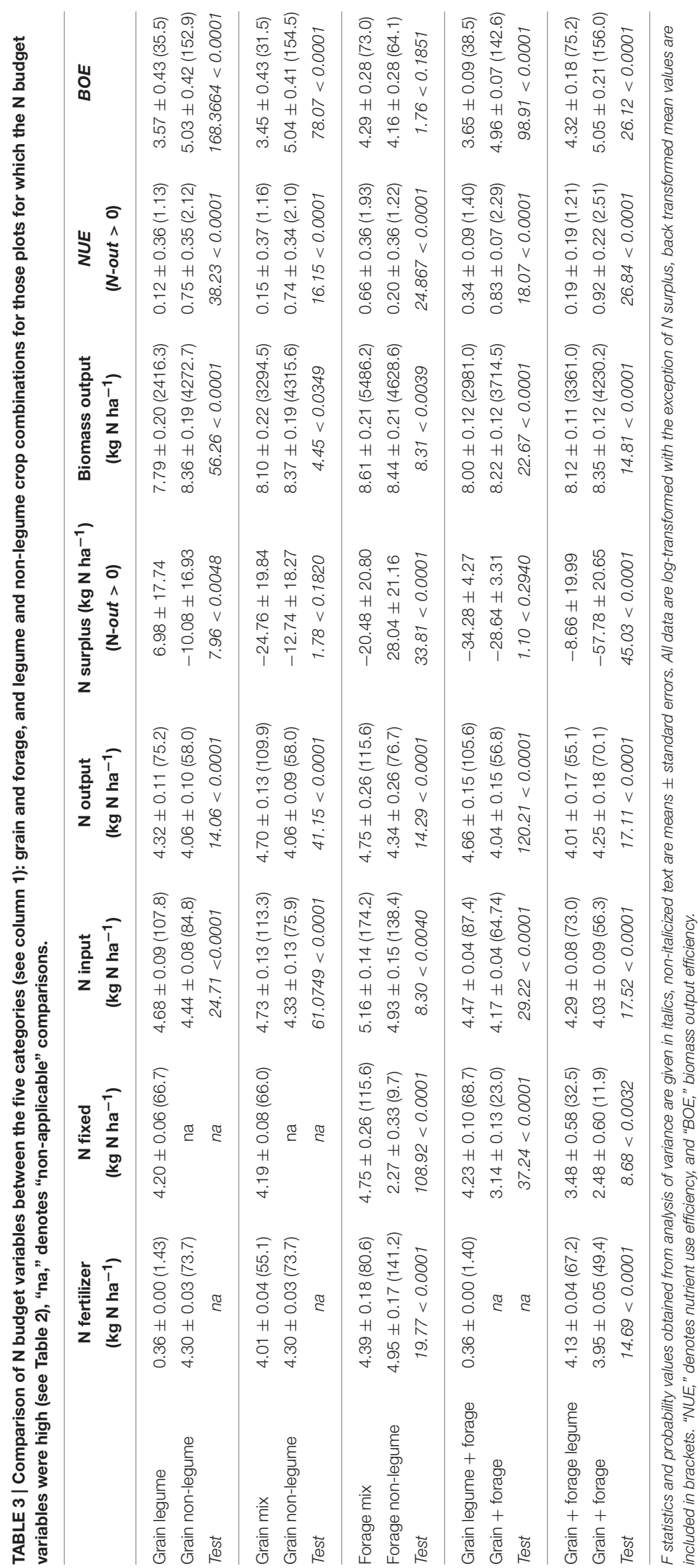




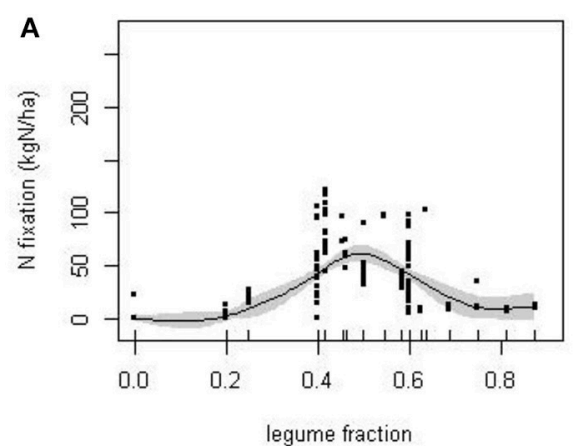

C

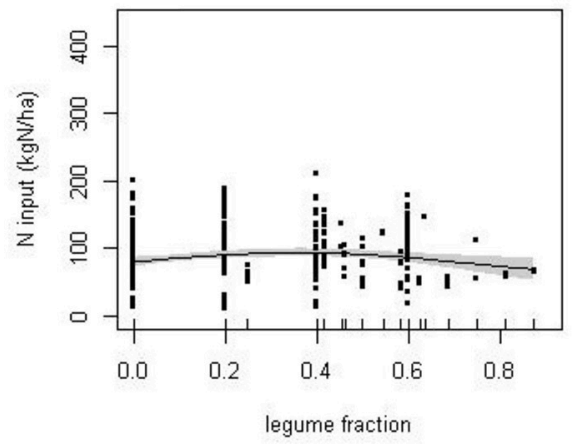

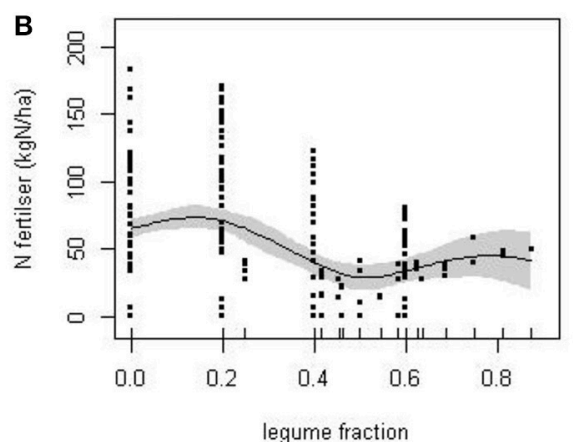

D

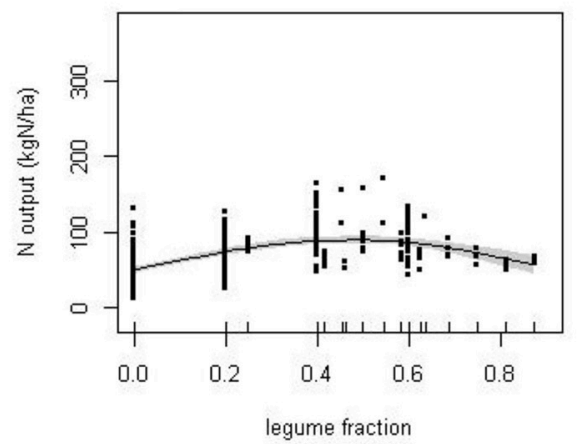

FIGURE 2 | The response of: (A), BNF; (B), N fertilizer input; (C), N input; and, (D), N output to the proportion of the experimental cropping sequences by year in which legumes were cultivated (legume fraction). Solid lines are estimated smooth functions obtained from fitted GAMs with standard errors given by the shaded areas.

was modified in favor of the legume for the one comparison that consisted of all-vegetative crops, namely the forage mix (e.g., clover and grass) and the forage non-legume (e.g., grass), where $\mathrm{N}$-out and biomass were both higher in the grass-legume mixture. The highest biomass and $N$-out among all comparisons were produced by this vegetative forage (all others having some "grain" component). The factor probably responsible for the higher productivity of these forages was the absence of a reduced photosynthetic capacity that normally occurs during reproductive growth, as a result of the requirement of the grain for $\mathrm{N}$, which usually triggers leaf senescence. There might also have been some niche complementarity between the vegetative legume $\mathrm{BNF}$ and the non-legume using applied $\mathrm{N}$, resulting in the forage mix having greater output than the comparator (Lüscher et al., 2014).

\section{N-Balance Approach}

The N-balance approach has the advantage that it allows systematic comparison of a wide range of disparate studies that could otherwise not be pooled for analysis, but inconsistencies can enter the analysis since no account is taken of internal cycling of N. Potential carry-over effects between years, e.g., through uptake from $\mathrm{N}$ pools in soil, "catch" crops that were purposely plowed and did not contribute directly to output, and persistence of legumes as volunteer weeds can all affect single-year estimates of $\mathrm{N}$-balance variables. However, the examination of the balance over the sequence should negate, or at least reduce, these potential complications.

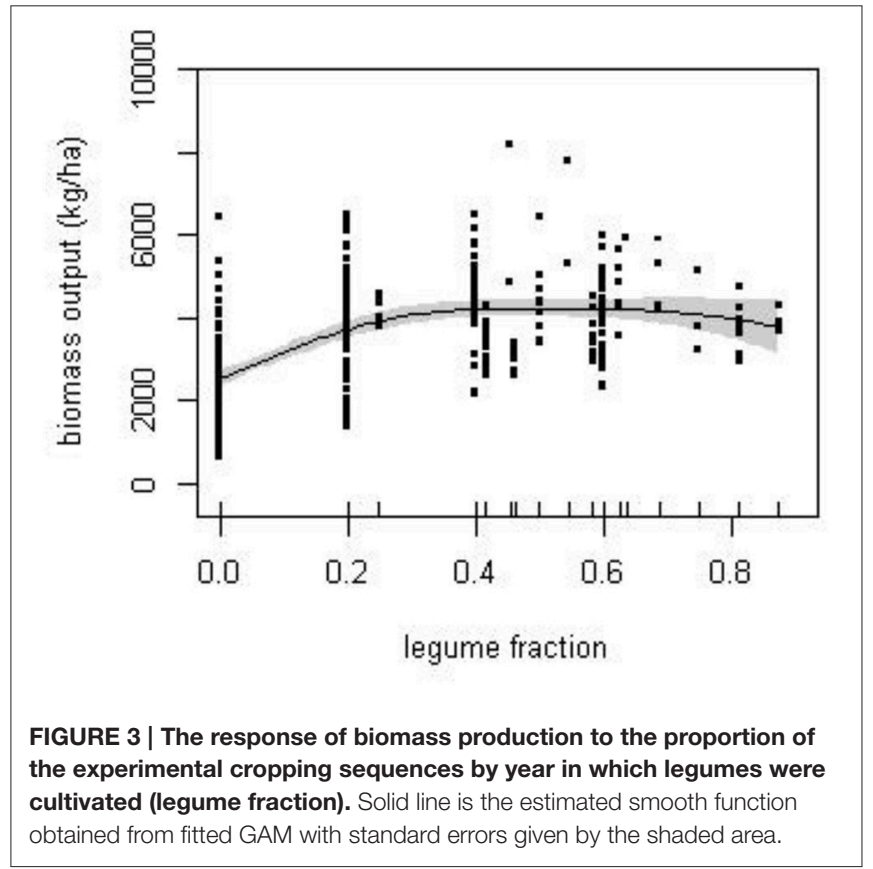

When considered over the sequence, both N-out (Figure 2) and to a lesser extent biomass (Figure 3) showed a broad maximum at legume fraction between 0.3 and 0.7 , within which highest values were between 0.4 and 0.6 . In contrast, 
the two components of $\mathrm{N}$-in varied systematically and generally in opposition in their contribution. Together these trends confirm the previous conclusion based on crop-year that BNF compensated for reduced mineral fertilizer in generating biomass.

Between legume fractions of 0.6 and 0.8 , the contribution of $N$-fix decreased. Most sequences in this range were forages that typically included legumes, either as intercrops or in relay, but were also given fertilizer, even in years when the legumes were present, such that $N$-fix was estimated as a smaller input than it was from grain legumes. These sequences nevertheless, through a combination of $N$-fert and $N$-fix, maintained high $N$-in, and $\mathrm{N}$-out and biomass. Therefore, the presence of legumes did not cause any systematic reduction in total output when assessed over the cropping sequence (Figure 3 ).

\section{Opportunity for Increasing BNF and Other Properties of Legumes in Multifunctional Systems}

The rates of output and $N$-fix were measured here in experimental systems, and with rotations, that included those designed for productivity in low-input or organic conditions. Nevertheless, $\mathrm{N}$-balance variables and yield were within the range of values commonly found in high input cropping. For example, the combined inputs of $\mathrm{N}$ by BNF and fertilizer, $\mathrm{N}$-in, ranged from 56 to $174 \mathrm{~kg} \mathrm{ha}^{-1}$ for the legumes, while mean $N$-fix ranged from 32 to $115 \mathrm{~kg} \mathrm{ha}^{-1}$ (Table 3, back-transformed means). In comparison, the typical mineral $\mathrm{N}$ input in conventional high input cropping in Europe is around $100 \mathrm{~kg} \mathrm{ha}^{-1}$ for a spring cereal and $200 \mathrm{~kg} \mathrm{ha}^{-1}$ for a winter cereal or oilseed (Fertiliser Practice, 2014). The most direct comparator for high input cereals is that of grain legume crops (the first comparison at the top of Table 3). Here, $N$-in for the grain legume was $108 \mathrm{~kg} \mathrm{ha}^{-1}$ and biomass output $2.4 \mathrm{t} \mathrm{ha}^{-1}$; while $\mathrm{N}$-in for the non-legume grain was $85 \mathrm{~kg} \mathrm{ha}^{-1}$ and biomass output $4.3 \mathrm{t} \mathrm{ha}^{-1}$. Given that grain yields for high-intensity cereals are typically $4-8 \mathrm{t}$ $\mathrm{ha}^{-1}$, the lower value being for spring crops, (Sylvester-Bradley and Kindred, 2009) the non-legume grains in this study are comparable with general yields, while the legume grains show the typical higher $\mathrm{N}$ and lower biomass in yield.

Higher values of $N$-fix than those recorded here should be feasible. While the agronomy underpinning the trials was advanced by conventional standards, no particular attempt was made to maximize the amount of $N$-fix. Indeed, the common inclusion of $\mathrm{N}$-fert in many of the sequences would have had the opposite effect. Moreover, values of $N$-fix estimated here were for current varieties that have been bred largely for conventional high-input cropping systems where there is generally much residual $\mathrm{N}$. The potential for improving BNF within existing species and varieties of grain legume needs to be considered. For example, faba bean has been shown to have a significantly greater effect than other legumes on the yield of subsequent cereal grain crops (Wani et al., 1991; Hauggaard-Nielsen et al., 2009, 2012). Therefore, legume breeding should aim for higher levels of performance directed at low-input environments, croppingsystems focused on energy as well as food and fodder production
(Porter et al., 2009; Jensen et al., 2012) and in both mixed cropping or intercropping (Brooker et al., 2014).

Legumes may have a range of benefits other than through $\mathrm{BNF}$ and potential as a green manure. Some degree of persistence by living legume plants to the next phase of the croppingsequence was found in a number of plots and while there may be risks of such carry-over (Driscoll et al., 2014), the production benefits from the legume forages and grains that persist into subsequent crops need to be quantified and exploited. Belowground phenology will also be important. Faba bean presents extensive tap roots capable of reaching deep into the soil profile, improving soil structure and benefiting the rooting profile of crops which follow them in the rotation (Rochester et al., 1998, 2001). In relation to this, the benefit of grain legumes to the yield of the next crop is greater than the benefit brought by carry-over of $\mathrm{N}$ in the soil. Some other factors are influencing yield positively, implying a cascade effect to other soil- and system-processes beyond enhanced soil $\mathrm{N}$ status (Danso and Papastylianou, 1992; Ehrmann and Ritz, 2014). This pre-crop benefit of grain legumes can lead to yield increases of up to $1.6 \mathrm{t} \mathrm{ha}^{-1}$ in subsequent cereals (Preissel et al., 2015). This is consistent with our own findings which assessed the pre-crop benefits of legumes at the rotational level, and which also suggest higher non-legume yield potential may be achieved in years after legumes. This reflects the higher $\mathrm{N}$ inputs achieved by legume supported rotations.

However, in tackling problems such as reducing $\mathrm{N}$ losses from agriculture, legumes should also have a role but as part of broader systems of management. Greenhouse gas emissions, for example, depend on the complex interaction of several different biotic and abiotic variables (Snyder et al., 2014). While legume supported crop systems may limit $\mathrm{N}$ and C losses (Drinkwater et al., 1998, maize-soybean), management per se is a major factor in achieving this (Rees et al., 2013), especially the use of cover crops, both legume and non-legume grown to accumulate $\mathrm{N}$ in the soil for potential incorporation by later crops and to reduce GHG emissions (Thorup-Kristensen et al., 2003; Li et al., 2015).

A more critical appraisal of the traits targeted by legumes breeders should consider these wider system benefits (Sinclair and Valdez, 2012). Improvements are feasible e.g. soybean demands manipulation by either agronomy or re-breeding to render it as a net "contributor" of N, as opposed to a net "taker" from the system (Alves et al., 2003; Perez de la Vega et al., 2011; Baddeley et al., 2013). Moreover, the purpose of legumes in mixed forage systems, both examined here and in the wider literature, is not simply to contribute BNF or in-field benefits, but to bring wider system benefits beyond the farm level e.g., as a forage with particular characteristics or through a combination of outputs that optimize biomass and $\mathrm{N}$ content (Danso and Papastylianou, 1992; Crews and Peoples, 2004; Foley et al., 2011).

\section{CONCLUSIONS}

The data assessed here were generated from very different experimental designs adapted to a wide range of pedoclimatic and socioeconomic conditions and presented a significant challenge 
to ensure they were harmonized to allow comparative analysis of a range of conventional, low-input and organic approaches. It is possible that a more marked efficiency benefit would have been realized if intensive systems had also been considered in the comparative analysis. Nevertheless, a model is suggested which proposes that optimum efficiency is achieved with an approximately equal balance of forage and grain legumes such that the legume fraction, the proportion of rotation years in which a legume is cropped, is around 0.4-0.6, with the legume component often accommodated as an intercrop.

Mathematical modeling studies have indicated that legume based crop rotations can deliver environmental and economic benefits (Reckling et al., 2016). However, the optimal rate of legume inclusion, such as the high inclusion levels reported here, should be tested and refined empirically with respect to the specific pedoclimatic and socio-economic contexts for those regions in which they are cultivated. Such tests should assume rotations which accommodate intelligent design principles which include agronomic approaches that mimic those assessed here for low-input, organic and often mixed cropping systems. Additionally, major challenges will remain, such as ensuring that losses though leaching and greenhouse gases are minimized. It is also important that effective integrated pest management strategies for legume supported systems are also developed.

\section{REFERENCES}

Alves, B. J., Boddey, R. M., and Urquiaga, S. (2003). The success of BNF in soybean in Brazil. Plant Soil 252, 1-9. doi: 10.1023/A:10241919 13296

Andersson, T. N., and Milberg, P. (1996). Weed performance in crop rotations with and without leys and at different nitrogen levels. Ann. App. Biol. 128, 505-518. doi: 10.1111/j.1744-7348.1996.tb07110.x

Andersson, T. N., and Milberg, P. (1998). Weed flora and the relative importance of site, crop, crop rotation, and nitrogen. Weed Sci. 46, 30-38.

Bachinger, J., and Reining, E. (2009). An empirical statistical model for predicting the yield of herbage from legume-grass swards within organic crop rotations based on cumulative water balances. Grass Forage Sci. 64, 144-159. doi: 10.1111/j.1365-2494.2009.00678.x

Baddeley, J. A., Jones, S., Topp, C. F. E., Watson, C. A., Helming, J., and Stoddard, F. L. (2013). Biological Nitrogen Fixation (BNF) in Europe. Legume Futures Report 1.5. Available online at: www.legumefutures.eu.

Bergkvist, G., and Båth, B. (2015). Nitrogen fertiliser dose influence the effect of two year rotational leys with grass or clover-grass on other crops in the rotation. Aspects Appl. Biol. 128, 133-139.

Bloch, R., Wechsung, F., Heß, J., and Bachinger, J. (2015). Climate change impacts of legume-grass swards: implications for organic farming in the Federal State of Brandenburg, Germany. Reg. Environ. Change 15, 405-414. doi: 10.1007/s10113-014-0656-2

Brooker, R. W., Bennett, A. E., Cong, W. F., Daniell, T. J., George, T. S., Hallett, P. D., et al. (2014). Improving intercropping: a synthesis of research in agronomy, plant physiology and ecology. New Phytol. 206, 107-117. doi: $10.1111 /$ nph.13132

Bullock, D. G. (1992). Crop rotation. Crit. Rev. Plant Sci. 11, 309-326. doi: 10.1080/713608037

Crews, T. E., and Peoples, M. B. (2004). Legume versus fertilizer sources of nitrogen: ecological tradeoffs and human needs. Agric. Ecosyst. Environ. 102, 279-297. doi: 10.1016/j.agee.2003.09.018

Danso, S. K. A., and Papastylianou, I. (1992). Evaluation of the nitrogen contribution of legumes to subsequent cereals. J. Agric. Sci. 119, 13-18. doi: $10.1017 /$ S0021859600071495

\section{AUTHOR CONTRIBUTIONS}

The approach was conceived jointly by GB and PI. The original data files were verified and collated in an openaccess (on request) Access ${ }^{\mathrm{TM}}$ database by MY. GB, PI and MY, jointly coordinated to collate and harmonized the datasets in a standard data-template, specifically designed for the soil-surface $\mathrm{N}$ balance analysis and to facilitate comparisons between trials. Data analysis and initial interpretation of the results was led and carried out by GB solely. GB, PI, MY, GS, RR and EJ played key roles in developing the final interpretation of the results, and finalizing the discussion. All other authors contributed the original datasets, and contributed to the preparation of the manuscript by recommending supporting scientific references and providing critical comment.

\section{FUNDING}

This research was supported with funding from EU-FP7 project Legume Futures (http://www.legumefutures.eu), under grant agreement number 245216 CP-FP. The James Hutton Institute and the Scottish Rural Colleges and the associated staff are also supported by the Scottish Government.

DEFRA (2010). Fertiliser manual RB209. London: Department for Environment, Food and Rural Affairs.

DEFRA (2011). Fertiliser Manual RB209. London: Department for Environment Food and Rural Affairs.

Doltra, J., and Olesen, J. E. (2013). The role of catch crops in the ecological intensification of spring cereals in organic farming under Nordic climate. Eur. J. Agron. 44, 98-108. doi: 10.1016/j.eja.2012. 03.006

Drinkwater, L. E., Wagoner, P., and Sarrantonio, M. (1998). Legume-based cropping systems have reduced carbon and nitrogen losses. Nature 396, 262-265. doi: 10.1038/24376

Driscoll, D. A., Catford, J. A., Barney, J. N., Hulme, P. E., Inderjit, Martin, T. G., et al. (2014). New pasture plants intensify invasive species risk. Proc. Natl. Acad. Sci. U.S.A. 111, 16622-16627. doi: 10.1073/pnas.14093 47111

EEA (2007). Europe's Environment, the Fourth Assessment. Copenhagan: European Environment Agency.

Ehrmann, J., and Ritz, K. (2014). Plant: soil interactions in temperate multicropping production systems. Plant Soil 376, 1-29. doi: 10.1007/s11104-0131921-8

Eriksen, J., Askegaard, M., Rasmussen, J., and Søegaard, K. (2015). Nitrate leaching and residual effect in dairy crop rotations with grass-clover leys as influenced by sward age, grazing, cutting and fertilizer regimes. Agric. Ecosyst. Environ. 212, 75-84. doi: 10.1016/j.agee.2015.07.001

Erisman, J. W., Sutton, M. A., Galloway, J., Kilmont, Z., and Winiwarter, W. (2008). How a century of ammonia synthesis changed the world. Nat. Geosci. 1, 636-639. doi: 10.1038/ngeo325

Fertiliser Practice (2014). The British Survey of Fertiliser Practice: Fertiliser Use on Farm Crops for Crop Year 2013. London: DEFRA.

Foley, J. A., Ramankutty, N., Brauman, K. A., Cassidy, E. S., Gerber, J. S., Johnston, M., et al. (2011). Solutions for a cultivated planet. Nature 478, 337-342. doi: 10.1038 /nature10452

Foresight (2011). The Future of Food and Farming Final Project Report. The Government Office for Science, London.

Hansen, J. (2000). Nitrogen Balances in Agriculture. Luxemburg: European communities. 
Hanson, J. D., Liebig, M. A., Merrill, S. D., Tanaka, D. L., Krupinsky, J. M., and Stott, D. E. (2007). Dynamic cropping systems. Agron. J. 99, 939-943. doi: 10.2134/agronj2006.0133s

Hauggaard-Nielsen, H., Mundus, S., and Jensen, E. S. (2009). Nitrogen dynamics following grain legumes and subsequent catch crops and the effects on succeeding cereal crops. Nutr. Cycling Agroecosyst. 84, 281-291. doi: 10.1007/s10705-008-9242-7

Hauggaard-Nielsen, H., Mundus, S., and Jensen, E. S. (2012). Grass-clover undersowing affects nitrogen dynamics in a grain legume-cereal arable cropping system. Field Crops Res. 136, 23-31. doi: 10.1016/j.fcr.2012.07.001

Houghton, J. T. (Ed.). (1996). Climate Change 1995: The Science of Climate Change: Contribution of Working Group I to the Second Assessment Report of the Intergovernmental Panel on Climate Change, Vol. 2. Cambridge, UK: Cambridge University Press.

IPCC (2006). Guidelines for National Greenhouse Gas Inventories. Institute for Global Environmental Strategies, Hayama, Kanagawa.

Jensen, E. S., Peoples, M. B., Boddey, R. M., Gresshoff, P. M., Hauggaard-Nielsen, H., Alves, B. J., et al. (2012). Legumes for mitigation of climate change and the provision of feedstock for biofuels and biorefineries: a review. Agron. Sustain. Dev. 32, 329-364. doi: 10.1007/s13593-011-0056-7

Korsaeth, A., and Eltun, R. (2000). Nitrogen mass balances in conventional, integrated and ecological cropping systems and the relationship between balance calculations and nitrogen runoff in an 8-year field experiment in Norway. Agric. Ecosyst. Environ. 79, 199-214. doi: 10.1016/S01678809(00)00129-8

Li, X., Petersen, S. O., Sørensen, P., and Olesen, J. E. (2015). Effects of contrasting catch crops on nitrogen availability and nitrous oxide emissions in an organic cropping system. Agric. Ecosyst. Environ. 199, 382-393. doi: 10.1016/j.agee.2014.10.016

Lopez-Bellido, R. J., Lopez-Bellido, L., Benitez-Vega, J., Muñoz-Romero, V., Lopez-Bellido, F. J., and Redondo, R. (2011). Chickpea and faba bean nitrogen fixation in Mediterranean rainfed Vertisol: effect of the tillage system. Eur. J. Agron. 34, 222-230. doi: 10.1016/j.eja.2011.01.005

Lüscher, A., Mueller-Harvey, I., Soussana, J. F., Rees, R. M., and Peyraud, J. L. (2014). Potential of legume-based grassland-livestock systems in Europe: a review. Grass Forage Sci. 69, 206-228. doi: 10.1111/gfs.12124

Nepstad, D. C., Stickler, C. M., and Almeida, O. I. (2006). Globalisation of the Amazon soy and beef industries: opportunities for conservation. Conserv. Biol. 20, 1595-1603. doi: 10.1111/j.1523-1739.2006.00510.x

OECD (2001). Environmental Indicators for Agriculture: Methods and Results, Vol. 3. Paris: OECD.

OECD (2008). Environmental Performance of Agriculture in OECD Countries Since 1990. Paris: OECD.

Pappa, V. A., Rees, R. M., Walker, R. L., Baddeley, J. A., and Watson, C. A. (2012). Intercropping: effect on yield and $\mathrm{N}$ balances in a three year crop rotation. J. Agric. Sci. 150, 584-594. doi: 10.1017/S0021859611000918

Parris, K. (1998). Agricultural nutrient balances as agri-environmental indicators: an OECD perspective. Environ. Pollut. 102, 219-225. doi: 10.1016/S02697491(98)80036-5

Perez de la Vega, M., Torres, A. M., Cubero, J. I., and Kole, C. (2011). Genetics, Genomics and Breeding of Cool Season Grain Legumes. Boca Raton, FL: Science Publishers, Inc.

Persson, T., Bergkvist, G., and Kätterer, T. (2008). Long-term effects of crop rotations with and without perennial leys on soil carbon stocks and grain yields of winter wheat. Nutr. Cycling Agroecosyst. 81, 193-202. doi: 10.1007/s10705007-9144-0

Porter, J., Costanza, R., Sandhu, H., Sigsgaard, L., and Wratten, S. (2009). The value of producing food, energy, and ecosystem services within an agro-ecosystem. AMBIO 38, 186-193. doi: 10.1579/0044-7447-38.4.186

Preissel, S., Reckling, M., Schläfke, N., and Zander, P. (2015). Magnitude and farm-economic value of grain legume pre-crop benefits in Europe: a review. Field Crops Res. 175, 64-79. doi: 10.1016/j.fcr.2015. 01.012

Reckling, M., Bergkvist, G., Watson, C. A., Stoddard, F. L., Zander, P. M., Walker, R. L., et al. (2016). Trade-offs between economic and environmental impacts of introducing legumes into cropping systems. Front. Plant Sci. 7:669. doi: $10.3389 /$ fpls. 2016.00669
Rees, R. M., Augustin, J., Alberti, G., Ball, B. C., Boeckx, P., Cantarel, A., et al. (2013). Nitrous oxide emissions from European agriculture-an analysis of variability and drivers of emissions from field experiments. Biogeosciences 10, 2671-2682. doi: 10.5194/bg-10-2671-2013

Rochester, I. J., Peoples, M. B., Constable, G. A., and Gault, R. R. (1998). Faba beans and other legumes add nitrogen to irrigated cotton cropping systems. Aust. J. Exp. Agric. 38, 253-260. doi: 10.1071/ EA97132

Rochester, I. J., Peoples, M. B., Hulugalle, N. R., Gault, R. R., and Constable, G. A. (2001). Using legumes to enhance nitrogen fertility and improve soil condition in cotton cropping systems. Field Crops Res. 70, 27-41. doi: 10.1016/S03784290(00)00151-9

Rochon, J. J., Doyle, C. J., Greef, J. M., Hopkins, A., Molle, G., Sitzia, M., et al. (2004). Grazing legumes in Europe: a review of their status, management, benefits, research needs and future prospects. Grass Forage Sci. 59, 197-214. doi: 10.1111/j.1365-2494.2004.00423.x

Scalise, A., Tortorella, D., Pristeri, A., Petrovičová, B., Gelsomino, A., Lindström, K., et al. (2015). Legume-barley intercropping stimulates soil $\mathrm{N}$ supply and crop yield in the succeeding durum wheat in a rotation under rainfed conditions. Soil Biol. Biochem. 89, 150-161. doi: 10.1016/j.soilbio.2015. 07.003

Seufert, V., Ramankutty, N., and Foley, J. A. (2012). Comparing the yields of organic and conventional agriculture. Nature 485, 229-232. doi: 10.1038/nature11069

Simon, M. F., and Garagorry, F. L. (2005). The expansion of agriculture in the Brazilian Amazon. Environ. Conserv. 32, 203-212. doi: 10.1017/S0376892905002201

Sinclair, T. R., and Valdez, V. (2012). The future of grain legumes in cropping systems. Crop Pasture Res. 63, 501-512. doi: 10.1071/CP12128

Snyder, C. S., Davidson, E. A., Smith, P., and Venterea, R. T. (2014). Agriculture: sustainable crop and animal production to help mitigate nitrous oxide emissions. Curr. Opin. Environ. Sustainabil. 9, 46-54. doi: 10.1016/j.cosust.2014.07.005

Sprent, J. I. (2009). Legume Nodulation: A Global Perspective. Chichester: Wiley Blackwell.

Sprent, J. I., and Sprent,. P. (1990). Nitrogen Fixing Organisms: Pure and Applied Aspects. London: Chapman and Hall.

Steinfeld, H., Gerber, P., Wassenaar, T., Castel, V., Rosales, M., and de Haan, C. (2006). Livestock's Long Shadow - Environmental Issues and Options. Food and Agriculture (FAO) of the United Nations document. Rome: FAO Publishing Management Service

Suter, M., Connolly, J., Finn, J. A., Loges, R., Kirwan, L., Sebastià, M. T., et al. (2015). Nitrogen yield advantage from grass-legume mixtures is robust over a wide range of legume proportions and environmental conditions. Glob. Chang1. Biol. 21, 2424-2438. doi: 10.1111/gcb.12880

Sutton, M. A., Howard, C. M., Erisman, J. W., Billen, G., Bleeker, A., Grennfelt, P., et al. (Eds.). (2011). The European Nitrogen Assessment: Sources, Effects and Policy Perspectives. Cambridge, UK: Cambridge University Press.

Sylvester-Bradley, R., and Kindred, D. R. (2009). Analysing nitrogen responses of cereals to prioritize routes to the improvement of nitrogen use efficiency. J. Exp. Bot. 60, 1939-1951. doi: 10.1093/jxb/erp116

Taylor, B. R., Younie, D., Matheson, S., Coutts, M., Mayer, C., Watson, C. A., et al. (2006). Output and sustainability of organic ley/arable crop rotations at two sites in northern Scotland. J. Agric. Sci. 144, 435-447. doi: $10.1017 /$ S0021859606006435

Thorup-Kristensen, K., Magid, J., and Jensen, L. S. (2003). Catch crops and green manures as biological tools in nitrogen management in temperate zones. $A d v$. Agron. 79, 227-302. doi: 10.1016/S0065-2113(02)79005-6

UNEP and WHRC (2007). Reactive Nitrogen in the Environment: Too Much or Too Little of a Good Thing. United Nations Environment Programme, Paris.

Vitousek, P. M., Aber, J. D., Howarth, R. W., Likens, G. E., Matson, P. A., Schindler, D. W., et al. (1997). Human alteration of the global nitrogen cycle: sources and consequences. Ecol. Appl. 7, 737-750. doi: 10.1890/10510761(1997)007[0737:haotgn]2.0.co;2

Vitousek, P. M., Cassman, K., Cleveland, C., Crews, T., Field, C. B., Grimm, N. B., et al. (2002). Towards an ecological understanding of biological nitrogen fixation. Biogeochemistry 57/58, 1-45. doi: 10.1023/A:1015798428743 
Wani, S. P., McGill, W. B., and Robertson, J. A. (1991). Soil N dynamics and N yield of barley grown on Breton loam using $\mathrm{N}$ from biological nitrogen fixation or fertilizer. Biol. Fertil. Soils 12, 10-18. doi: 10.1007/BF00369382

Watson, C. A., Baddeley, J. A., Edwards, A. C., Rees, R. M., Walker, R. L., and Topp, C. F. E. (2011). Influence of ley duration on the yield and quality of the subsequent cereal crop (spring oats) in an organically managed long-term crop rotation experiment. Org. Agric. 1, 147-159. doi: 10.1007/s13165-011-0012-5

Conflict of Interest Statement: The authors declare that the research was conducted in the absence of any commercial or financial relationships that could be construed as a potential conflict of interest. The reviewer SDSK and handling
Editor declared their shared affiliation, and the handling Editor states that the process nevertheless met the standards of a fair and objective review.

Copyright (c) 2016 Iannetta, Young, Bachinger, Bergkvist, Doltra, Lopez-Bellido, Monti, Pappa, Reckling, Topp, Walker, Rees, Watson, James, Squire and Begg. This is an open-access article distributed under the terms of the Creative Commons Attribution License (CC BY). The use, distribution or reproduction in other forums is permitted, provided the original author(s) or licensor are credited and that the original publication in this journal is cited, in accordance with accepted academic practice. No use, distribution or reproduction is permitted which does not comply with these terms. 